\title{
RIGHT TO FOOD: AN EMERGING HUMAN RIGHTS JURISPRUDENCE?
}

\section{EL DERECHO A LA ALIMENTACIÓN: ¿UNA JURISPRUDENCIA EMERGENTE DE DERECHOS HUMANOS?}

\section{VIRGINIA ZAMBRANO}

Doutora em Dottorato en Giurispurdenza pela Universita degli Studi di Napoli Federico II (1992). Atualmente é Professor of Comparative Law da Università degli Studi di Salerno. Tem experiência na área de Direito, com ênfase em Direitos Especiais.

\begin{abstract}
Objective: To demonstrate that the effectiveness of the right to food is strictly dependent on the adoption of appropriate public policies, capable of guaranteeing conditions of transparency and information, and granting individuals and groups the possibility to participate in the taking of decisions. Next, the focus is on the role played by the courts to address the issue of legal consideration of this right.
\end{abstract}

Methodology: The study methodology included the analysis of jurisprudence on the right to food, as well as the constitutional recognition of the right to food. Likewise, the position of the courts and the political aspect of the right to food were challenged.

Results: It has often been discovered that people are not even aware of the possibility of using litigation as a tool to promote the realization of the right to food. As well as the lack of knowledge on the part of politicians to implement public policies to realize this essential right to food.

Contributions: The main contribution lies in realizing that it is not at stake or in the recognition of this right by the courts. While it is true that the role of the courts is essential because it facilitates the creation of a cultural climate sensitive to human rights, it is also true that the implementation of rights through jurisprudence means that the problem of access to justice is resolved.

KEYWORDS: Fundamental rights; right to food; food sovereignty; legal consideration (justiciability); comparative law. 


\section{RESUMEN}

Objetivo: El objetivo de este ensayo es demostrar que la efectividad del derecho a la alimentación es estrictamente dependiente de la adopción de políticas públicas apropiadas, capaces de garantizar condiciones de transparencia y información, y otorgar a individuos y grupos la posibilidad de participar en la toma de decisiones. A continuación, la atención se centra en el papel desempeñado por los tribunales para abordar el problema de la justiciabilidad de este derecho.

Metodología: La metodología del estudio comprendió el análisis de la jurisprudencia sobre el derecho a la alimentación, así como el reconocimiento constitucional del derecho a la alimentación. Asimismo, se cuestionó la posición de los tribunales y el aspecto político del derecho a la alimentación.

Resultados: A menudo se ha descubierto que las personas ni siquiera son conscientes de la posibilidad de utilizar el litigio como herramienta para promover la realización del derecho a la alimentación. Así como a la falta de conocimiento por parte de los políticos para implementar políticas públicas para hacer realidad de este derecho esencial a la alimentación.

Contribuciones: La contribución principal radica en darse cuenta de que no está en juego ni en el reconocimiento de este derecho por parte de los tribunales. Si bien es cierto que el papel de los tribunales es fundamental porque facilita la creación de un clima cultural sensible a los derechos humanos, también es cierto que la implementación de los derechos a través de la jurisprudencia supone que se resuelva el problema del acceso a la justicia.

PALABRAS-CLAVE: Derechos fundamentales; derecho a la alimentación; soberanía alimentaria; justiciabilidad; derecho comparado.

\section{SOME PRELIMINARY REMARKS}

In the late 1980s in Taiwan, the government expanded the imported quantity of agricultural products, damaging the local farmers. Ru and his brother, Cai, personally witnessed the dramatic change of circumstances that led their family to poverty.

In 2002, Taiwan officially joined the WTO, and the Taiwanese government encouraged farmers to let their land lie fallow. Abandoned farmlands turned into industrial landfills caused many injuries to children who used to play in the fields. 
Politicians, in cahoots with unscrupulous entrepreneurs, also made the situation worse by selling the land to them. Ru experienced the agriculture decline of his country and tried to approach several relevant government sectors, hoping they could amend the economic policies in order to offer more support to local farmers. But all efforts were vain. He then decided to speak out on behalf of farmers. He packed 17 harmless selfmade "rice" bomb, not only to remind the government and society of the agricultural issues but also to force them to take these problems seriously. Attached to the devices (November 2003/November 2004) were notes that stated "Against rice importing. The government should look after its people". Among onlookers, Ru waiving in the breeze, reminisced about the beautiful rice fields from his childhood. Even though only two of the bombs caused damages, $\mathrm{Ru}$ was sentenced to 7 years in prison, for having compromised public security. His protest urged the government to face up to the difficulties continuing to affect farmers in Taiwan (THE RICE BOMBER, 2014).

This story gives food for thought.

Farming, as everybody knows, has an enormous impact on the world's most critical resources. Not only does it imply the need to guarantee people enough food, it also underlies the importance of ensuring sustainable food and agriculture systems. Agriculture and food are therefore closely interconnected. Just as close is the link between agricultural development and the economy. In fact, agricultural development affects the production of food, the economy and the environment and is therefore capable of influencing the conduct of economic operators and creating conditions of competitiveness. On the other hand, food is a good that, from an economic point of view, can be exchanged and become a source of profit. From this point of view, the rationalization of the production of food and an adequate price policy seem to generate the ideal climate to ensure food availability. The current 'more production' orientation is responsible for many environmental issues, and also impairs the right of all human beings to adequate and healthy food (WESTRA, 2015, p.18).

The question is not only, or not simply, how to ensure "more" production. According to Amartya Sen, while there is enough food, relatively few people can benefit from it (DREZE; SEN, 1991; ZIEGLER, et al., 2011, p.23). Hunger, in other words, can be considered a matter of systemic inequality rather than one of underproduction or 
overpopulation, or a consequence of natural constraints. In this context, we should ponder on whether there is any possibility of improving both production and the food system. Could we think of a solution that, while offering a profound re-thinking of our current models of production, would serve our needs better? On a global level, food production is facing multiple limiting factors. On the one hand, we have as many overweight people as malnourished people, and on the other, the consequences of our emerging dietary habits are on a dreadful path for human health as well as for the ecosystem. There is even more.

The high percentages of food wasted in the so-called "developed" countries show how agriculture policies mostly concentrate on production and trade, and are oddly divorced from the vital issues of good nutrition. The central idea is that "beauty is good" (RICHARDS, et al., 2011, p.29-47). It has been said that "the oligopolistic nature of many developed countries' agri-food chains effectively make supplier compliance to 'private' standards mandatory" (DAVEY, RICHARDS, 2013, p.271-281). Fruit, vegetables and all kind of foodstuff have to comply with strict quality regulations. But for farmers, having 'quality' standards based upon appearance that results in produce not being harvested and sold, if such produce is safe to eat, is of no interest at all. Such standards lead to avoidable food losses at the farm level.

Not to consider that the agri-food systems of modern society are closely tied to environmental degradation, and are at the origin of political instability due to higher food costs, or to its shortages. In this landscape, problems of hunger, food prices linked to the multiple effects of population growth, energy markets, questions of employment, climate change, land degradation, concentration in the number of firms managing the global distribution of food supplies contribute to a food-related crisis, due to the inefficient use of food-related resources and impair a human right ${ }^{1}$.

1 Inter alia, see IANNARELLI, 2015, p. 3 ss. Passim; ROSSI, 2015; FORNO; GRAZIANO, 2016; IMBRENDA, 2016; PENNASILICO, 2018, p. 11 ss.; ALOGNA, 2016, p. 145 ss. 


\section{THE DUAL NATURE OF FOOD: FOOD AS A FUNDAMENTAL GOOD}

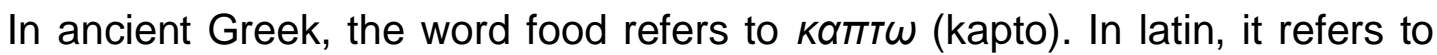
"capio", i.e. to feed, eat. Food is the amount of nourishment that animals "need" to remain alive. For men, it is better to use the word alimentum. The alimentum has more general properties, as it allows growth of the body and the mind: it is what nourishes the person.

The Oxford Latin Dictionary defines nutrimentum with precision: "That which feeds or sustains, nourishment (also fig.: to what feeds an emotion); 2. (plu.) Upbringing, nurture (of a child)". Thus, from an etymological point of view, the word food is multifaceted. Food can indicate the commodity, the object of the exchange. It can be the single vegetable the animals eat. For humans, however, food is what nourishes and is therefore essential to the well-being of the person: "Cibo autem maxime sustentandus est, ut habeat corpori nutrimentum"2. Food is therefore a complex concept, a source of rights of a different nature, which give rise to different subjective legal positions.

The complexity derives from the fact that food is at the crossroads of reflections concerning both the profile of economic production and the consumption, as well as issues related to the right to life, health, housing, education, freedom of association, right to work and safety. In short, food is a "fundamental good", because it is strictly connected to the essential needs of the human being and, to the extent that it exceeds the ability to access the vital minimum, it is an asset that interests the market. The nature of the "fundamental good" and, therefore, its being functional to the development of the person and to his dignity, explains why food should be considered a fundamental right. According to Ferrajoli, fundamental rights are those rights (he refers to "diritti soggettivi"), universally belonging to all human beings, who have the status of persons, citizens, or persons capable of acting. Whereas, "subjective rights"

\footnotetext{
2 Flauius Vegetius Renatus, Digesta artis mulomedicinae CXVII said "Food serves for the sustenance of the human being, for the b RINELLA ody to have its nourishment": PRENCIPE, 2015, p. 75.
} 
mean any absolute right that creates positive (performance) or negative (non-injury) obligation ${ }^{3}$.

The right to food is, in this sense, a fundamental right. And, in fact, the universalism that complements the recognition of the right to food is expressed in papers and international documents in which the need to ensure "an adequate standard of living" which, of course, includes food, goes hand in hand with the need to implement an adequate strategy for the elimination of hunger ${ }^{4}$.

The value of the right to food, its significance, is crystallized in expressions that show how the recognition of the right to food goes through the birth of authentic (positive and negative) obligations of the States, which must take appropriate steps to ensure the enjoyment of this right. The State, in other words, has to respect, protect and fulfil this right ${ }^{5}$ that is, it must provide the necessary tools to ensure effective protection of this basic and fundamental right, by improving the conditions of access to food, or by introducing "principles of accountability, transparency, people's participation, decentralization, legislative capacity and the independence of the judiciary”.

Actually, universality implies accessibility, that is, the development of conditions making effective the abstract recognition of the right, avoiding any market logic that could hinder its realization. In practice, though, the processes of food production, distribution and consumption, are organized around the market and the interests of the stakeholders who control the chain of distribution. In this landscape,

\footnotetext{
${ }^{3}$ FERRAJOLI, 2001, p. 5; ZIEGLER, 2008; ALSTON, 1984, p. 12; LAMBEK; CLAEYS, 2016, p. 744 ss. ${ }^{4}$ Art. 25(1) Universal Declaration of Human Rights; art. 11 International Covenant on Economic, Social and Cultural Rights (ICESCR), (right to adequate food and the fundamental right to be free from hunger); CEDAW (entered into force 3 September 1981); Convention on the Rights of the Child, (entered into force 2 September 1990); Convention on the Rights of Persons with Disabilities, (entered into force 3 May 2008); Fao, Voluntary Guidelines To Support The Progressive Realization Of The Right To Adequate Food In The Context Of National Food Security (2004), http://www.fao.org/3/a-y7937e.pdf ; Additional Protocol to the American Convention on Human Rights in the Area of Economic, Social and Cultural Rights (entered into force 16 November 1999, (Protocol of San Salvador); African Charter on the Rights and Welfare of the Child, opened for signature 11 July 1990, OAU Doc. CAB/LEG/24.9/49 (art 14, entered into force 29 November 1999); United Nations Committee on Economic, Social and Cultural Rights (CESCR).

${ }^{5}$ General Comment No 15: The Right to Adequate Food, 12 May 1999, ESCOR [2000] Supp 2, 102. (General Comment No 15).

${ }^{6}$ Committee On Economic, Social And Cultural Rights (Cescr), N. 23.
} 
not only does the need for fossil fuels and the proliferation of agro-fuels endangers the accessibility to food, it also implies a question of food sovereignty. The State's policies, and the development of food security and preservation of rural/peasant communities, face more and more with the power of capital to organize and reorganize agriculture ${ }^{7}$.

The question of access to food, therefore, is interconnected with the paradigm of food sovereignty and the implementation of strategies that ensure an increasing democratic control and participation in policymaking decisions about food and agriculture (LAMBEK; CLAEYS, 2016, p. 789).

\section{FOOD AS A COMMODITY}

In the debate on the right to food, however, the philosophical/legal dimension is associated with a political/economic profile that involves the question of the level of intervention by the State in the market and the level of control of the commercial flows.

The dual legal nature of food depends on the fact that it is not only a "fundamental good", but also, like any other commodity, that it can be traded on the market. The growing intervention of economic operators in the production, processing, distribution and consumption of food is creating the conditions for the birth of a real "corporate food regime" organized around profit, which compromises its universality. In this food commodification process, also the financial instruments developed by the market, such as hedge funds, futures and swaps, are used to cover the risks deriving from fluctuations in the price of agricultural products, linked to environmental disasters or under-production factors.

In such a climate, the economic development, according to a neoliberal approach, is conceived as an increase in the overall well-being, generated by the multiplication of efficient transactions. But the intervention of capital as "independent

\footnotetext{
${ }^{7}$ FRIEDMANN; MCMICHAEL, 1989, p. 95. RINELLA, 2015, p.20. It has been noted that "Il denaro delle multinazionali determina il comportamento degli stati e spesso delle organizzazioni non governative": CAPRA; MATTEI, 2017, p. 154. In Africa, for example, multinationals have financed the spread of GMOs or favored the elimination of ancient agricultural practices.
} 
player" in exchanges concerning food alters, inevitably, the social equilibria and increases inequalities by penalizing the poor more heavily.

In the State/market dialectic, the pursuit of public good is no longer the product of State intervention in the market in terms of rebalancing, but is entrusted to a "shorttermism" strategy in which individual economic operators define the market objectives. On these premises, for example, are moving the regulatory measures adopted by the USA government, as the Commodity Futures Modernization Act 2000, aimed at reducing regulatory oversight in financial transactions. The liberalization of the financial market, by attenuating the regulatory authority of the Commodity Futures Trading Commission (CFTC) over security warrants, mortgages, repurchase agreements, swap etc., reduces the monitoring for transactions and makes price manipulation easier. The economic effects of this type of strategy are obvious. The expulsion from the productive cycle of small farmers is the result of a pricing policy that favours large multinationals.

The transformation of law into a mere infrastructure used by the economy to achieve its objectives ${ }^{8}$ not only accentuates inequalities but also it damages the environment; and the costs of these damages are not measured by the economy. "In the market system - De Grauwe says - there is nothing to prevent companies and consumers from generating external costs, unless there is a State intervention capable of curbing the current profiteering. In other words, there is no internal regulatory mechanism for which the environment can oppose to the external costs which are ultimately passed on it" (DE GRAUWE, 2018; RINELLA, 2015, p.25). There is more.

\footnotetext{
${ }^{8}$ IRTI; SEVERINO, 2001, passim. More specifically, IRTI, 2001, p. 64, notes "Gli atti economici possono accadere in qualsiasi luogo, e distribuirsi in un luogo e nell'altro (qui la produzione, lì il consumo; qui la sede dell'impresa, lì la raccolta dei capitali); ma questa mobilità e flessibilità non costituiscono un tutto, non rivelano un significato d'insieme. Ciascun atto è soltanto se stesso". See, KLEIN, 20017, p. 399. Analysing the behaviour of the "economic actors", after the tsunami, in Sri Lanka, the A. observes that "residents were barred from rebuilding, but hotels were showered with incentives; temporary camps were miserable militarized holding pens, and almost no permanent reconstruction had been done; entire ways of life were being extinguished. It concluded that the setbacks could not be chalked up to the usual villains of poor communication, underfunding or corruption. The problems were structural and deliberate: "Governments have largely failed in their responsibility to provide land for permanent housing, " [...]. They have stood by or been complicit as land has been grabbed and coastal communities pushed aside in favour of commercial interests",
} 
The process of fragmentation of identities that characterizes modern societies challenges the idea of the State as a subject able to protect the interests of an undifferentiated community. The rise of a set of differentiated (and sometimes antithetical) interests reacts on the person's ability to oppose to the violation of environmental rights or even human rights.

Thus, for example, the environment protection is challenged daily by the need to maintain employment growth and economic competitiveness. As the tradable part of the global economy (goods and services produced in one country and consumed in another) expands, competition for economic activity and jobs broadens, making it hard to determine, in the conflict between environment/employment, what the prevailing interest is. At issue is the need to ensure the access to food, by rebalancing the public and the market through the development of appropriate public policies

The right to food should be assumed as a whole concept, since its realization depends on the coordination of different provisions and policies (concerning trade law, health, education, social protection, finance etc.) more than on a series of fragmented laws aimed at protecting single, specific interests (i.e., consumers, minors, workers etc.).

The development of a food security strategy implies a systemic approach including a variety of accountability mechanism to monitor its implementation as well as food policies that should not be side-tracked by changes in political power.

While is it true that the diversity of interests concerned with food highlights the multidimensionality of the theme and the difficulty of developing a systemic approach to the issues it raises, it is relatively insignificant compared to the need to explore "some existing legal instruments that could or should be used to eliminate hunger" (WESTRA, 2017, p.120). The problem cannot be solved by simply relying on a concept of universality that does not seem to escape from a façade dimension. Nor the legal protection of the right to food relies on its being established in constitution.

The recognition of this right is challenged by the fact that its implementation, as we will see, depends on many factors, some legal, some others economic.

Even when States (as it has happened in Brazil, with the "Bolsa familia" program) make normative efforts to grant the effectiveness of the right to food, they 
don't really get rid of a welfare dimension, without creating the conditions for an effective participation (ARANHA, 2010, p.74-95).

The sustainability of efforts to eradicate hunger can only be achieved when those at risk are aware, empowered and have access, at all times, to accountability instruments that effectively promote and protect their human right to adequate food. Claiming a right, in fact, is different from obtaining its effective recognition and being able to implement it. In addition, it is clear that the insertion of new rights in the Constitution (when not complemented by adequate policies) is a mere manifestation of façade that behind universalizing declarations hides a true hegemonic power (KNUTH; VIDAR, 2011; PRETEROSSI, 2008, p.279-289).

\section{THE CONSTITUTIONAL RECOGNITION OF THE RIGHT TO FOOD}

The direct or indirect recognition of the right to food, as a fundamental right, is linked, inextricably, to the dignity of the human person (as enshrined in the Universal Declaration of Human Rights of 1948 and recognised in the International Covenant on Economic, Social and Cultural Rights). However, assessing the effectiveness of the right to food is a complex issue. In the legal discourse, the question seems to be only hinted at. Even when the Constitutions expressly recognize this right, its implementation faces many constraints.

The theoretical-juridical approach is formal and hyper-normative, that is, scarcely attentive to the dimension of effectiveness. As if to say that the mere constitutionalization of the right to food, even when expressly recognized, does not seem able per se to grant its effectiveness. To be challenged is the normative value of the constitutional norm, which leaves in the background the "structural" question of the economic-political power (PERLINGIERI, 2006, p.538). The regulatory power of the law does not take into account the influence of the economics on the political and legal discourse, which is able to put in danger the same existence of the human rights (PISTOR, 2019). This aspect, although connoting itself in an epistemological sense, calls into question law, politics and, of course, public ethics (SHIVA, 2015, p.68). 
The mention of the right in the Constitutions is certainly indicative of a choice of value made by the legal systems and has a double meaning. On the one hand, it is an invitation to the public authorities to take the necessary steps to implement the principle and to oblige all public, political, administrative and jurisdictional authorities, in carrying out their duties, to implement the principle (MINKLER; PRAKASH, 2015). The express constitutional provision of the right to food grants it a special "status", by imposing the adoptions of a certain type of policies to the State.

On the other hand, the constitutional norm, because of its legal value, should empower people to complain against those acts that violate their fundamental rights. Actually, the constitutional norm works primarily like a linguistic medium whose purpose is "to realize a moral value as well as a concrete reference to the rule of law" (ZAGREBELSKY, 2002, p.877), as the complex nature of the right to food (as a social right) impairs its implementation. In this sense, the fact that the right to food "has been increasingly integrated into constitutions and legislations, as well as policies, strategies and programmes" means only that the implementation and recognition of this right should be conceived as a process (FAO, 2011, p.28) $)^{9}$. Nor do legal systems adopt always the same normative technique to recognize this right.

There seem to be at least three different ways of giving relevance to the right to food. These different approaches not only create the conditions for political tensions and local resistance, but also affect the ways in which legal intervention techniques are designed to safeguard the right to food.

Sometimes in Constitutions this right is explicitly stated, some others it is simply referred to through the enshrinement of the right to an adequate standard of living (art. 27.2 Const. Sri Lanka or art. 28, c.1, Const. Indonesia). In some other Constitutions, the right to food is only hinted at (Const. Ghana, art. 36). In those Constitutions where express reference is made to the right to food, the legal provision often seems to be a mere vehicle for a programmatic manifestoes (artt. 2, 4 Const. Mexico; art. 16, Const. Bolivia; art. 13 Const. Ecuador; art. 27 South Africa; 44

\footnotetext{
9 The awareness of the length and complexity of this process is well illustrated in the long, but wellmotivated, decision of the Corte Constitucional de Colombia, T-25/2004, in www.corteconstitucional.gov.co.
} 
Colombia; art. 6 Brazil Const.) (LAMBEK; CLAEYS, 2016, p.789). On the other side stand those legal systems that, taking an holistic approach to human dignity, refer to a general improvement of the life's conditions (art. 41 Const. Ethiopia) and to a "sustainable development" (art. 43.3 Const. Ethiopia). Egypt provides a good example of a State that, instead of taking a right approach, has underlined the obligation of the State to "ensure reasonable food resources to all citizens (...) and also sustainable food sovereignty" (art. 79 Const. Egypt).

However, while the fundamental rights discourse, at least in its more abstract dimension, has found momentum in the modern constitutions, little progress has been made in creating an environment in which the ESC rights (and the right to food in particular) could be fully realized in national contexts. In fact, the obligation, for the State, to fulfil the right to food, leaves unaddressed the core question of the problem, since the endorsement of this right need structural changes aimed at decreasing food insecurity.

Even when the recognition of the right to food, appear as a more general goal, or directive principle within the constitutional order - as, for instance, in the provision of art. 36 Ghana Const. (1996), establishing that the State has to provide for "adequate means of livelihood and suitable employment and public assistance to the needy", the major barrier to achieving the enjoyment of this right is in the lack of political will to really protect this rights. In the same article, the Ghana Const. states as well (art.36.4) that "Foreign investment shall be encouraged within Ghana, subject to any law for the time being in force regulating investment in Ghana". The attention payed to employment, production and productivity reveals the complexity of establishing a fair balance between the interests served by economy and a sustainable development, respectful of fundamental human rights.

Under this point of view, the need for economic development makes African countries particularly vulnerable ${ }^{10}$. In the attempt to attract foreign investors, those

\footnotetext{
10 It has been said that, in Africa, the communitarian approach "rappresenta una chiave fondamentale per sviluppare un dialogo sui diritti umani con quelle culture che, a differenza dell'ideologia liberale di matrice occidentale, non riconoscono il tratto individualistico dei diritti", PEGORARO; RINELLA, 2017, p.255. The Banjul Charta, entered into force on 21 Oct. 1986, shows the uniqueness of the African culture and the significance that assists the theory of rights and freedoms, not always in line with the
} 
countries have adopted constitutions that while pointing out to the food security, focus on the principle of economic freedom too. Human rights are than denied as a result of dubious corporate activities that not only influence agricultural policies, but also follow growth-oriented economic policies to achieve short-term political and budgetary benefits. In the constitutions, the use of the words "reasonable" or "sustainable", or even the reference - as is the case in Venezuela ${ }^{11}$ - to a progressive achievement of certain objectives, reveals a "strategic" use of the law, which proves the political dimension of economic and social and cultural rights (ESCR). A clarification, however, is called for.

In this case, the conceptual framework of this fundamental right is shaped by the judges unable to get rid of a theoretical and dogmatic approach that sclerotizes the legal discourse, leaving it prey of mere abstractions. In so doing they end up in underlying only the "fulfilment" aspect, without entering into the dynamics (more political and economic of the right to food), which lie behind the profile of "respecting" and "protecting".

The example of Nigeria is emblematic. In the absence of adequate public policies, the courts have been called to articulate policy reasons for recognizing the people's right to live with dignity and participate in society. The right to "adequate means of livelihood" is included in the Section relating to "Non-binding Directive Principles of State Policies" (Ch. II of the Const.) and is therefore considered "subsidiary" to the Fundamental rights and cannot be executed ${ }^{12}$. The fact that, in

western legal tradition. More. The communitarian dimension, sometimes, increases the power of states to arbitrarily interpret its provisions.

${ }^{11}$ Artículo 19. El Estado garantizará a toda persona, conforme al principio de progresividad y sin discriminación alguna, el goce y ejercicio irrenunciable, indivisible e interdependiente de los derechos humanos. Su respeto y garantía son obligatorios para los órganos del Poder Público de conformidad con la Constitución, los tratados sobre derechos humanos suscritos y ratificados por la República y las leyes que los desarrollen.

12 Nigerian Constitution, Ch.II, Art. 16, (2) The State shall direct its policy towards ensuring: (d) that suitable and adequate shelter, suitable and adequate food, reasonable national minimum living wage, old age care and pensions, and unemployment, sick benefits and welfare of the disabled are provided for all citizens. But this provision has a mere programmatic character, as the interest in economic development is predominant. The non-binding aspect of the DPSP is highlighted by section 6(6)(c) of the Constitution. In Archbishop Okogie $v$ The Attorney-General of Lagos State 19811 NCLR 218232 , the judges says: "In any event, it seems to me that the Directive Principles of State Policy in Chapter II of the Constitution have to conform to and run as subsidiary to the Fundamental Rights under Chapter IV of the Constitution. If there is no infringement of any Fundamental Right there can be no objection to 
Federal Republic of Nigeria $v$ Anache $(2004,14$ WRN 1. Nigeria), the judges have recognized the justiciability of this right - as a consequence of Nigeria's accession to the African Charter (adopted by the OAU: Nairobi, Kenya, 27 June 1981, and entered into force on 21 Oct. 1986) - doesn't change the fact that Nigerian judiciary is, on the whole, not in sympathy with the idea of enforcing the right to food.

Even though many factors impair the realization of this right, its constitutional recognition should, at least, foster the adoption of food sovereignty policies aimed at providing access to land to the poor, favouring less industrial practices, participation and promoting agriculture.

The adoption of policies aimed at strengthening the participation of the community (such as in Bolivia or Brazil), while increasing the State control over agriculture and natural resources, have not infrequently faced important challenges, such as women's economic and political empowerment (baldiviezo; aguilar, 2006; CATACORA-VARGAS, et. al., 2017).

In Brazil, the assessment of nutritional status as complementary to food insecurity, has promoted the adoption of a series of social programs to ensure the human right to adequate food, with the aim of reducing social vulnerability within the family, in a sustainable way (GUBERT, et. al., 2017; BRAZIL, 2004). Running out of food, having to reduce dietary quality, or having to practice unusual coping strategies to access food appears, in fact, as a consequence of the political-economic crisis; a crisis that affect, mainly if not exclusively, the socially most vulnerable families. The Zero Hunger Project was aimed at building, under the umbrella of participation, a National Policy for Food and Nutritional Security Plan (Política Nacional de Segurança Alimentar e Nutricional - PNSAN), to define management procedures and mechanisms for the monitoring and evaluating of State actions on food. The enactment of the Brazil's 2006 food security law (LOSAN, lei 2006/11346) and the adoption of a Sistema Nacional de Segurança Alimentar e Nutricional (SISAN) to coordinate decentralised public policies and to develop a dialogue with other public policy legislative and executive powers conferred on the State". But for a different approach, Uzouku v. Ezeonu II, 1991, 6, NWLR (Pt 200) 761. 
systems, including the health, education, social assistance, shows the effort made by the government to bring together different parts of the public administration and civil society service providers (LEÃO; MALUF, 2012). The constitutional amendment no. 64,2010 , that includes the right to food among the social rights, has than offered the normative basis for a process of negotiation between different sectors of the government (BRAZIL, 2003).

Sometimes, as in India, the constitutional provisions has been used as a tool to force the legislator to enact a national food program.

In a carefully reasoned decision dated Nov 30, 2001, the Supreme Court of India ruled in favour of the People's Union for Civil Liberties (PUCL) who had petitioned the court for the enforcement of both the food Indian national schemes and the Famine Code, a code permitting the release of grain stocks in times of famine. People's Union for Civil Liberties v Union of India must be considered as an Indian leading case in assessing the obligation of the State to provide food to people in drought-affected areas who cannot purchase or produce it themselves.

While acknowledging some constitutional rights, the court recognized the right to food as deriving from the right to life. In this connection, it emphasized the nature of the Indian constitution, progressive and dynamic in itself and deemed to ensure justice, equity and liberty to each citizen of India. While the right to food is not a fundamental right explicitly mentioned in part III of the Indian constitution, the courts held that it can be derived from article 21 Const. which implies that, in order to live, one needs food: deprivation of food explicitly implies a violation of the right to life.

More importantly, there was the problem of creating a mechanism for the continuous monitoring of the implementation of public policies and court's decisions. Article 47 Indian Const. (part IV) under directive principles of the state policy says that "The State shall regard the raising of the level of nutrition and the standard of living of its people and the improvement of public health as among its primary duties and, in particular, the State shall endeavour to bring about prohibition of the consumption except for medicinal purposes of intoxicating drinks and of drugs, which are injurious to health". Emphasizing the paramount importance of the food, the court concluded that the State must ensure an adequate amount of nutritious food to people, for their 
sustainability. In other words, the right to life cannot be restricted to mere animal existence.

In releasing a series of "orders", the court transformed the government food schemes into "legal entitlements provided by a constitutionally protected right to food and the beneficiaries of these programs into "stakeholders of justiciable rights" (GERSEN, et. al., 2018, p.1068.). The same in Francis Coralie Mullin v Union Territory of Delhi and others ${ }^{13}$. For the court, the right to life is something more than just physical survival, as it implies adequate nutrition and the realization of the human dignity.

Which lesson could we learn from these case law? Even when in Constitutions there is no express reference to the right to food, its constitutional protection is "adequate" where this right has been adjudicated according to a fundamental right approach. As the judgment of the courts amply demonstrates to overcome the wellknown problems related to the justiciability of the ESCR, they develop a legal discourse in which food and personal dignity are closely interrelated.

Sometimes, their decision has been used as a sword to force the government to enact appropriate laws. In so doing, not only has the judiciary played an important role, working as an enforcer and protector of human rights, it has also influenced the activity of the legislator. Thus, they have stepped away from the role-game of judges and have given impetus to social transformation. However the judicial protection neither can work as substitute for the improvement of a general human rights culture nor can replace the legislators, even though it plays (as said) a pivotal role in the rise of a cultural climate in which some normative changes can occur.

\section{THE JUSTICIABILITY OF THE RIGHT TO FOOD}

The inalienable, unavailable, universal character of fundamental rights should be reflected in the type of protection guaranteed by the State, in order to recognize the basic and fundamental goods or, rather, those goods deemed functional to the

${ }^{13}$ Francis Coralie Mullin v. Union Territory of Delhi and others, 1981 AIR 746, 1981, SCR (2) 516. 
development of the human being. The question of justiciability of the right to food - as that of many social rights - involves the fact that social rights appear too nebulous and indefinite to be adjudicated. The judicial protection of these rights would involve - as we have seen - an intrusion by judges into areas traditionally reserved to public authority. Another aspect is that social rights entail issues that are too complex to be solved by courts.

The problem of social rights, in other words, is closely linked to multiple factors: the identification of procedures for bringing a claim to court; the manner in which courts adjudicated the right; and, of course, the remedies awarded in successful case law and so on. Although symptomatic of a particular sensitivity toward a culture of fundamental rights, the mention to the right to food in the Constitutions, does not depart from a pure programmatic dimension, as the realization of social rights depends on the ability to organize public resources for the realization of the services in which the social right consists.

This explains why - in the few cases where judges confronted with the justiciability of the right to food - they have been extremely cautious. The caution arises from the fact that, generally speaking, the constitutional process (at least in Italy) is not designed to sanction the omissions of the legislator. As if to say that the remedial perspective is extraneous to the technique of the constitutional process, making difficult the identification of the sanction once the infringement of the right has been ascertained. When the judges declare the unconstitutionality of the law, they refer to the constitutional principle that must be respected by the law, in order to be considered compliant with the Constitution. In these sentences, they do not grant petitioners any relief. In the only case in which the Italian constitutional judges have dealt with the right to food, they referred to it as "social rights" and expressly recognized that the national legislator must take the necessary steps in order to alleviate situations of extreme need, in particular associated with problems of poverty and food ${ }^{14}$.

Of course, the idea that individuals, or other private entities, could go to court, complaining about the infringement of a constitutionally protected right violated by

${ }^{14}$ Corte Costituzionale, 15 gennaio 2010, n. 10, in Giur. cost., 2010, 1, p. 135. 
administrative, jurisdictional, legislative acts or omission is not new. But even when there exists a "constitutional jurisdiction of liberties" (amparo in Spain, Beschwerde in Austria and Verfassungsbeschwerde in Germany) to protect fundamental rights, the existence of a series of procedural rules works as a limit to the possible justiciability of the right (PEGORARO; RINELLA, 2015, p.576; ZENGERLING, 2013, p.77).

In those jurisdictions (Brazil, India, South Africa, Mexico) where the conditions for a direct justiciability of the right to food are not challenged, effective judicial protection is subject to the existence of mechanisms of access to justice by disadvantaged persons. In Latin American systems, for example, the amparo is connected to the judgment on the constitutionality of the laws only in a potentially manner and it is used to protect the violation of fundamental rights (ZENGERLING, 2013, p.271).

In those systems (Brazil, India, South Africa, Mexico) where the need to ensure access to justice by disadvantaged people is particularly strong, special procedures such as "class action"; habeas corpus; mandado de segurança (in Brazil it has as its object the violation of personal freedom) which represent the true pillar of constitutional justice - open the door to complaints about the violation of a fundamental right.

Another way of making effective the judicial protection of the right to food is represented by the existence, in some legal systems, of mechanisms that allow private organizations to act in the name of the disadvantaged. The recognition of Public Interest Litigation - the purpose of which is to protect the interests of people not having the culture and resources necessary to access the jurisdiction - allows NGOs or nondirectly injured parties to bring an action in order to represent collective interests. It is exactly what happened - as we will see later - in the case of People's Union for Civil Liberties. Although not provided for in the Constitution, the Public Interest Litigation has been accepted by the Indian Supreme Court since the 1980s in order to allow poor people to have access to justice ${ }^{15}$. The justiciability of the right to food is therefore linked to its "identification" in the legal system, as well as to the possibility of being

${ }^{15}$ Francis Coralie Mullin v. Union Territory of Delhi and others, 1981; GOLAY, 2009, passim. 
asserted before a judicial or quasi-judicial body that upholds its competence and decides the case.

If it is true that the protection of human rights against the abuses of the State is well summarized in the international Treaties, and sometimes in Constitutions, which impose on them the obligation to respect, protect and fulfil human rights; it is also true that the involvement of multinational companies in the violation of the various human rights raises also the questions of the responsibilities of private actors. Just to say that, even when the dialectic of fundamental rights overcomes the apparent vagueness of the discourse developed around the idea of "basic and natural rights" ${ }^{16}$, the right to food - as a fundamental right - faces many difficulties in gaining also an horizontal direct effect (Drittwirkung).

What the right to food narrative misses is the direct application of the public rule of law to economic relations between private individuals (unmittelbare Drittwirkung). Nor should this be surprising, as the "human right discourse" has not been elaborated with a view to relations between individuals (CLAPHAM, 1983, p.181182; JÄGERS, 2002). So that, in spite of the emphasis on fundamental rights, which should express the substantial dimension of democracy, the central, practical, questions still remain unsolved: 1. Who enjoys the right? 2. Against whom may the right be enforced? 3 . Who enforces the right? Can certain rights be held by individuals and even be enforced against other individuals?

\section{THE COURTS AND THE POLITICAL ASPECT OF THE RIGHT TO FOOD}

In People's Union for Civil Liberties v Union of India, art. 21 and 47 of the Indian Constitution (incorporated in part III under fundamental rights), have been used to consider the right to food as part of a more general right to live, guaranteed in any civilized society. For the petitioners, this right implies the right to food, water, a decent

\footnotetext{
${ }^{16}$ The recognition of these rights should not depend on their being included in a Constitution, TARELLO, 1976, p. 610; DWORKIN, 1977, p.11, observes that "Individual rights are political trumps held by individuals".
} 
environment, education, medical care and shelter ${ }^{17}$. The argument developed by the constitutional judges is based on the observation that the entire Constitution has to be read as an integrated whole. The principles of harmony, completeness and exhaustiveness of the written constitution, imply that the Constitution should be interpreted in a manner that promotes its purpose, values and principles, advances the rule of law and human rights.

In the case at stake, petitioners criticized the negligence of the Indian State in organizing the Public Distribution System (PDS), and the judges attested that the right to food had to be interpreted as part of the fundamental and human right to "life with human dignity." In so doing, they also issued several ad Interim Decision against the India's PDS, in order to compel the State to fulfil its obligations under art. 12 Indian Constitution. By appointing special Commissioners to monitor the execution of the various welfare schemes framed by the Government of India, the Supreme Court has then contributed to defining gradually the right to food in terms of the right to life. In this way, the judges' orders have reformulated the nutrition-related government schemes, as constitutionally protected legal entitlements and set out how those schemes should be implemented. But judicial activism ${ }^{18}-$ it is interesting to note that, since the inception of the case in 2001, 427 affidavits and 71 IA's (interlocutory applications) had been filed - also contributed to the enactment of a series of National Programs (INDIA, 2013), aimed at framing a new and fresh scheme of Public Distribution System, for a more rational distribution of food. In this context, the recent National Food Security Act, in 2013, stresses the importance of food and nutritional security in the human life cycle approach. Even though the Act has been criticized because "it will create demand pressures, which will inevitably spill over to market prices of food grains", evident is the shift from a welfare approach to a more right-based one (GULATI, 2013).

\footnotetext{
17 See for further cases, Olga Tellis \& Ors vs Bombay Municipal Corporation [1986 AIR 180, 1985 SCR Supl. (2) 51], where judges say " the easiest way of depriving a person of his right to life would be to deprive him of his means of livelihood to the point of abrogation"; C.E.S.C Ltd. Vs. Subhash Chandra Bose [1992 AIR 573, 1991 SCR Supl. (2) 267].

${ }^{18}$ Ahmedabad Municipal Corporation $v$ Nawab Khan Gulab Khan \& Ors [1996] Insc 1300 (11 October 1996). The same in Chameli Singh and Ors. v. State of U.P. and Anr . [1996] 2 SCC 549 referring to the right to everyone "to an adequate standard of living for himself and for his family including food, clothing, housing and to the continuous improvement of living conditions".
} 
The lesson we can learn from this case is evident.

While the courts are only concerned with the rights enshrined in the Constitution, the food stands as a political question, the implementation of which depends on many conditions, some related to the economy, others related to corruption and lack of transparency and accountability by the government. By finding a nexus between the right to life (as fundamental right enshrined in art. 21 and 47 Indian Const.) and the right to food (as part of a general right to life) the Indian judiciary has given teeth to the question of the justiciability of social rights.

The political aspect of the right to food is envisaged too in The High Court Of Kenya At Nairobi Petition No. 22 of $2012^{19}$. The reference to the right to food as enshrined in art. 43 of the Kenya Constitution (in art. 11 of the ICESCR, and implicitly in Articles 4, 16 and 22 of the African Charter) had been used by petitioners to ask a mandatory injunction to return the petitioners to the land from which they had been evicted, by a Company planning the exploitation of the area. By quoting what African Commission said in the Ogoni case ${ }^{20}$, the petitioners referred to art. 24 of the African Charter, in order to declare the obligation of the State in recognizing (as clearly stated in the UNDRIP) "that indigenous peoples have the right to the conservation and protection of the environment and the productive capacity of their lands or territories" ${ }^{21}$. The right to a healthy environment, in fact, requires the State to take reasonable steps and other measures to prevent pollution and ecological degradation, to promote conservation, and to secure an ecologically sustainable development use of natural resources.

What is interesting to note is that the judges have adapted the reliefs granted, to the specific case. The intent is to respond appropriately, and to remedy to, the violations of the law affecting the Petitioners, as well as to ensure the proper, lawful

\footnotetext{
${ }^{19}$ Mohamed Ali Baadi and Others v Attorney General, High Court of Kenia at Nairobi (No. 22 of 2012) (April 2018).

${ }^{20}$ African Commission on Human and Peoples' Rights, The Social and Economic Rights Action Center and the Center for Economic and Social Rights v. Nigeria, Communication 155/96, judgement of 27 May 2002.

${ }^{21}$ See art. 29, UN Declaration on the Rights of Indigenous People, UN Doc. A/RES/61295, as adopted by the Kenian government on the 13 September 2007.
} 
implementation of the already approved Development Project ${ }^{22}$. For the judges, even though the proposed Project could cause environmental degradation and (as, a consequence, of that) the violations of human rights, what is at stake is the lack of an "effective programme of public participation by the local community in Lamu County, during the conceptualization and implementation of the LAPSSET Project and its various individual components" 23 .

If it is true that this type of decisions is deeply related to social rights, it is equally worth remarking how the judges use the participation argument to emphasize that "environmental issue must be addressed by all or - at least - a majority of those affected by their outcome, not just by the minority, comprising the government and leading private sector-actors (p. 59)".

Nevertheless, in trying to respond to the discontent of the residents of Lamu County, the fundamental rights doctrine is used, to curb the economic interests and to reaffirm that the right to life "includes the right to live with human dignity and all that goes along with $\mathrm{it}^{22}$. In this decision, the judges seem well equipped to deal with the human rights discourse as they offer a robust interpretation of the values enshrined in the Kenian Constitution of 2010. The reference made to International Treaties as well as to foreign case law, demonstrate clearly the efforts to strengthen the theoretic basis of their decision.

Sometimes, even though (according to Constitution) the ESCR are not deemed justiciable, the fact that the country (in this case, Nigeria) had signed the African Charter on Human and People's Rights has been considered as an opportunity for giving effect to those rights. Assuming that the military government of Nigeria had been involved, with the Shell Petroleum Development Corporation (SPDC), in the exploitation of the Ogoniland, two NGO's filed a complaint to the African

\footnotetext{
${ }^{22}$ At issue, was the implementation of a large infrastructure and transportation project (LAPSSET: Lamu Port-South Sudan Ethiopia Transport Corridor), including the built of oil pipelines, a railway and a number of berth port.

${ }^{23}$ at D), let. i, p. 103. The expressed principle is in compliance with art. 189 of the Kenian Const.

${ }^{24}$ At 282, p. 77, quoting what Indian Court ruled in Maneka Gandhi v. Union of India (1978) 2 SCR 621 , p. $620-621$.
} 
Commission ${ }^{25}$. The fact that the Nigerian government did not take part in the procedure doesn't reduce the value of the decision. For the Commission, no distinction can be made between political and social rights, as they stand on equal foot. Under this perspective, applying the Velázquez test the violation of the human rights makes responsible the State "not because of the act itself, but because of the lack of due diligence to prevent the violation or to respond to it, as required by the Conventions" 26 . In this way the Commission refers to the lack of a process aimed at investigating and ascertaining the risks, for the population and the environment, deriving from the exploitation of the area. By pointing out to the obligations of the State, and analysing art. 4 (right to life), art. 16 (right to health) and art. 22 (right to development) of the African Charter, the Commission outlines also the true nature of the right to food. The decision has received positive comments, because it sentences the State to provide for a good compensation, the environmental recovery, and the relocation of the Ogoni.

But - apart from the correct considerations on the not reasonable distinction between political and social rights - the "Ogoni case" tells us more ${ }^{27}$, especially if we consider that the decision has never been implemented.

Not only it casts light on the poor attention payed to the environment by the Oil Extractive Companies. The fact that the decision has not been implemented discloses the existing "dangerous liaisons", between these companies and authoritarian governments that systematically violated human rights. The case of gas flaring offers another example of how dangerous and pervasive this relationship can be.

In Gbemre v. Shell Petroleumt, after an accurate analysis of national law (the Evironmental Assessment Act 2004 and the Associated Gas Re-Injection Act 1985) the Supreme Nigerian Court ruled that the gas flaring is illegal and against fundamental human rights. For the judges, the law under which this kind of activity is allowed is inconsistent with the right to life and the human dignity and, therefore,

\footnotetext{
${ }^{25}$ The Social and Economic Right Center and the Center for Economic and Social Rights $v$. Nigeria (2001) AfComHR, case n. 155/96, decision of 27 May 2002; COOMANS, 2002, pp. 749-760 .

${ }^{26}$ Velázquez Rodriguez v. Honduras, Inter-American Court of HR, judgement of 19 July 1988, Series C, n. $4, \S 166$, p. 172.

${ }^{27}$ African Commission on Human and Peoples' Rights, The Social and Economic Rights Action Center and the Center for Economic and Social Rights v. Nigeria, cit. On this topic, see STEYN, 2014, p. 57 ss.; ISMAIL, O.; UMUKORO, 2011, pp. 290 ss.; DAN-MUSA, 2013.
} 
"unconstitutional, null and void by virtue of Section I (3) of the same Constitution"28. The judges are aware of the fact that fundamental rights are part of the person's identity and, on these premises, they do not hesitate to condemn the Shell. However, if the legal frame is offered by a Western-style constitution, reality returns a legal context in which the law is used to create "networks" that bind together political and economic actors.

It is no coincidence that even though the court has recognized the responsibility of the big oil multinationals companies, deemed guilty of environmental disasters (at the origin of the reducing crop production and the adversely impacts on food security), no step has been taken by the oil companies to capture the gas and put it to a good use. The law itself (Associated Gas Re-Injection Act 1985), aimed at reducing gas flaring, was enacted only after the Nigerian government had settled, with the oil companies, the amount of fine to be paid in case of its violation ${ }^{29}$. The shift of the legal discourse towards the economy creates a disconnect between the geopolitical interests and the global economic context which moves towards the principles of economic efficiency ${ }^{30}$. The flexibility of the law, required by global investors, is functional to the operation of financial markets as their interest is to control the law and govern its interpretation. In this direction, they build narratives based on the economic development that show, if accurately analysed, their storytelling purpose. Under this point of view, the law is used as a tool that creates wealth as well as inequalities, since it is firmly placed in the service of foreign capital ${ }^{31}$. The dogma of "participation", frequently referred to by the judges in their grounds of decision to restore the decision-

${ }^{28}$ Gbemre $v$. Shell Petroleum Development Company Nigeria Limited and Others (2005) AHRLR 151 ( $\mathrm{NgHC} 2005)$.

${ }^{29}$ Fines are too low and handed out in very few instances, that's why oil companies don't care about the law. The judges on this respect, says "6. That section 3(2)(a) and (b) of the Associated Gas ReInjection Act and section 1 of the Associated Gas Re-Injection (Continued Flaring of Gas) Regulations section 1.43 of 1984, under which gas flaring in Nigeria may be allowed are inconsistent with the applicant's rights to life and/or dignity of human person enshrined in sections 33(1) and 34(1) of the Constitution of the Federal Republic of Nigeria, 1999 and articles 4, 16 and 24 of the African Charter on Human and Peoples' Rights (Ratification and Enforcement) Act, cap A9, vol 1, Laws of the Federation of Nigeria, 2004) and are therefore unconstitutional, null and void by virtue of section 1(3) of the same Constitution".

${ }^{30}$ See, NICOLINI, 2018, p. 112.

31 "Capital coded in portable law is footloose; gains can be made and pocketed anywhere and the losses can be left where they fall", PISTOR, 2019, p. 9 ss. RINELLA, 2015, p.30 ss. 
making power of local communities works as a mere statement of principle, since the negotiation process is absolutely asymmetrical ${ }^{32}$.

The formation of what has been termed "spazio politico liscio", as expression of a global economic order (MONATERI, 2013, p.6; NICOLINI, 2018, p.338) makes also irrelevant the analysis of how certain principles penetrate the legal systems, i.e., by way of the Constitution, the adherence to international treaties, or the incorporation of treaties into national laws. No doubt that the level of attention payed by the national courts to the fundamental rights depends on the ability to identify the values that underpin the interpretation of the laws. Nevertheless the correct identification of the values is a difficult task, especially when in dispute there are conflicting interests.

Even when the judiciary, on the issue of the justiciability of the ESCR, takes on its responsibility and refuses to play in favour of "groups of interests", the "capital code" performs strategies able to influence the political profile in its institutional manifestation and so frustrate the enforcement of the decision ${ }^{33}$.

A famous case involving the justiciability of ESCR and environmental interests is the one decided by the Corte Constitutional de Colombia. In trying to analyse the nature of the ESCR, and setting a hierarchy of values, the judges say "el carácter progresivo de ciertos derechos y la dimensión prestacional de un derecho exigen de las autoridades racionalidad en el diseño y articulación de las políticas públicas relativas a tales derechos, de tal manera que éstas sean transparentes, serias y coherentes, como expresión de los principios establecidos en el artículo 209 de la Carta. La transparencia exige que se hagan públicas las prestaciones que serán garantizadas así como los responsables de cumplir lo jurídicamente establecido. La seriedad demanda que cuando una política sea articulada en un instrumento jurídico,

\footnotetext{
32 The oil companies, in fact, use their economic power to engage the local communities and get their consent. According to WALLACE, 1981, pp. 239 ss. the policy followed by the oil companies with the complicity of the government ignores the question of the food, the health and other fundamental needs. The oil companies, when negotiate with local community, rather decide the "if, when and how "of the negotiation. Not infrequently, they rely on practices that feed into the conflict, such as paying youth gang not to protect flow station or deciding the amount of compensation to give communities for land acquisition and oil spill, STEYN, 2014, p. 75.

${ }^{33}$ As Gbemre v. Shell Petroleum Development Company Nigeria demonstrates, while the African Commission was dealing with the "obligation of the State", the Shell Petroleum had already settled the tort lawsuit in USA.
} 
como una ley o un decreto, se respete la fuerza normativa, no política ni retórica, de dicho instrumento y por lo tanto se definan los alcances de los derechos reconocidos y se precise el contenido de las correspondientes obligaciones estatales. La coherencia apunta a que exista concordancia entre, de un lado, lo que "promete" el Estado y, de otro lado, los recursos económicos y la capacidad institucional para cumplir lo prometido, máxime si las promesas se han transformado en normas jurídicas. La coherencia exige que si el Estado crea un derecho prestacional específico por vía de una ley, prevea que debe contar con los recursos para garantizar su goce efectivo y con la capacidad institucional para atender la demanda de servicios generada por la creación de ese derecho específico.

Ahora bien, cuando las autoridades competentes que conocen las características de un problema social, adoptan instrumentos jurídicos o promueven su expedición por el Congreso de la República, y tales instrumentos jurídicos no articulan una política pública cualquiera, sino que propenden por el goce efectivo de derechos constitucionales fundamentales, el juez de tutela puede ordenar que se respeten los criterios de racionalidad mínima anteriormente señalados. Ello puede implicar que se asegure la coherencia entre lo jurídicamente ordenado por normas adoptadas por los órganos competentes y los recursos necesarios para cumplir lo ordenado" 34 . In other words, the State must fulfill its mission. He is under the obligation to develop public policies and to create the conditions for giving people the rights they are entitled to, as once a "derecho prestational" has been recognized, then the State has to "atender la demanda de servicios generada por la creación de ese derecho específico".

Some conclusions can, therefore, be drawn.

\footnotetext{
${ }^{34}$ Corte Constitucional de Colombia, T-25/2004, in www.corteconstitucional.gov.co. In this decision the Court, according to the international obligations assumed by the State regarding human rights and the international humanitarian law, has condemned the State as "El goce efectivo de los derechos de fuerte contenido prestacional - como los derechos sociales - depende de que el Estado cree y mantenga las condiciones para dicho goce y adopte políticas encaminadas a su progresiva realización [....] En cuanto a las órdenes necesarias para superar la vulneración masiva y continua de los derechos de la población desplazada originada en factores estructurales, la Corte declarará la existencia de un estado de cosas inconstitucional y lo comunicará a las autoridades con responsabilidades en el tema, para que adopten, dentro de la órbita de sus competencias, y en un tiempo razonable, los correctivos que sean necesarios".
} 
The first point at issue is that, if the national legislators adopt a human right approach in enacting the law, and if the rules are properly applied by the public administration, then the dispute arising by the violation of the right to food must be adjudicated by the national courts. The intervention of the Regional Human Rights Courts (the Inter American Court of HR or the African Court for Human and People's Rights) raise, in fact, question of equitable access to justice and redistributive justice (ZENGERLING, 2013, p.115), not to mention the problem of the recognition of their jurisdiction. Nevertheless the attention paid to the right to food contributes to the development of a jurisprudence whose role is to build a "cultural climate" that consolidates centrality, secularity and impartiality of the judge. In Sawhoyamaxa Indigenous Community of the Enxet People v. Paraguay, the IACtHR did not hesitate to blame the conduct of the State for not protecting the rights of indigenous communities ${ }^{35}$.

On this premise, the judges awarded compensation, for material and nonmaterial damages, to local communities which had been deprived (for pure economic reasons) of the land of their ancestors. In condemning the State, not only has the court ordered to remedy the violations of the right to food, housing, health, and education of the children of impoverished communities. It has also imposed on the government the obligation to create a "development fund" to implement health, educational and agricultural projects.

As it is clear from the cases examined, the violation of the right to food is often used as an argument to underlie the failure of the State to meet its obligations ${ }^{36}$.

However, the decisions of the courts don't seem to go beyond a deterrent effect, as the recognition of this right does not depend only on the courts. Rather, it is strictly linked to the adoption of appropriate public policies capable of ensuring - as the Columbian constitutional judges say - conditions of transparency and information,

\footnotetext{
${ }^{35}$ Sawhoyamaxa Indigenous Community of the Enxet People v. Paraguay (2006) IACtHR Series C No 146, para 248.

${ }^{36}$ A. Antonio Jaramillo, A. Polania Montano, A. Maria Nuñez y otros: Sentencia No T-025 de 2004 de la Corte Constitucional, 22 de enero de 2004.
} 
in order to give individuals and groups - once identified the legal basis for their claim the possibility to participate in the decision-making process ${ }^{37}$.

\section{A POSSIBLE CONCLUSION?}

The discourse on the right to food is certainly complex and refers to the relationship between law, ethics, environment and economy. The economic sciences tell us that it is not easy to find a balance between primary interests of the person and interests that, although important, do not touch the foundation of existence. In this sense, the regulation of economic legal relations cannot be separated from an ethical component that should guide the market choices.

In fact, it is not possible to reduce the law to a simple technique of social organization. Law has "the function of historically creating a system of values distinct and superordinate to purely economic values" (MENGONI, 1985, p.147ss., spec, p.158). In the regulation of the trade and the market, the patrimonial interests must be subordinated to the non-pecuniary interests of the person, respecting a hierarchy of values that sees in the person and in the protection of his dignity, an important point of reference. The space recognized to human rights in Conventions, International Treaties, Constitutional Charters is certainly indicative of the acquired centrality of the person as well as of human rights.

But the ascription to the ranks of human rights, while attributing to the right to food its authentic theoretical dimension, is not sufficient to create the conditions to ensure its effectiveness. The right to food, invariably affirmed in international documents, does not depart from a merely programmatic dimension, which entrusts its implementation to the legislator and, even before, to its strategic choices in the economic field.

37 RODOTÀ, 2014: "The states are called to eradicate hunger. But they share this responsibility with a wider audience of international and national actors"; BUSSANI, 2010, p. 143. 
What is at stake is not even the acknowledgement of this right by the courts. If it is true that the role of the courts is fundamental, because it facilitates the creation of a cultural climate sensitive to human rights, it is also true that the implementation of rights through the case law, is assuming that the problem of access to justice is solved. Very often, people are even not aware of the chance of using litigation as a tool to advance the realization of the right to food (ELVER, 2014).

Nor are public authorities fully aware of their obligations. In this context the effectiveness of the right to food arises as an essentially political matter, since it requires the public authorities to make choices that respect the rights of young people, women, farmers, indigenous communities and, more generally, weak people. The panorama, from the point of view of the recipients of these social policies, is extremely complex. Only conditions of transparency, accessibility, real participation in economic choices and democratic self-determination, affecting inequalities, can guarantee an effective situation of empowerment.

The aim - not easy to achieve - is a development based on ecological education, fair sharing of common goods and generative ownership, because "trends towards ecological justice and sustainability are embedded in the organizational structures of society" (CAPRA; MATTEI, 2017, p.186).

\section{REFERÊNCIAS}

AFRICAN CHARTER. The African Charter on the Rights and Welfare of the Child (ACRWC). 1990.

ALOGNA, I. "La circolazione del modello di sviluppo sostenibile. Prospettive di diritto comparato per un percorso multidirezionale". In: FERONI, G. C.; FROSINI, T.E.; MEZZETTI, L.; PETRILLO, P. L. (a cura di), Ambiente, energia, alimentazione. Modelli giuridici comparati per lo sviluppo sostenibile, I, 1, in cesifin.it, 2016.

ALSTON, P. "International Law and the Human Right to Food". In: The Right To Food,The Right To Food, P. Alston \& K. Tomasevski eds., 1984.

ARANHA, A. V. "Fome Zero: a construção de uma estratègia de combate à fome no Brasil". In: Coleção Fome Zero: uma història brasileira, vol. I, Brasilia, 2010 
BALDIVIESO, Eleodoro; AGUILAR, Luis Carlos. Metodología de pequeños productores para mejorar la producción agrícola. Estrategias locales para la gestión de riesgos. Altiplano Paceño, Bolivia. Edición: Agencia Suiza para el Desarrollo y la Cooperación (COSUDE) Impreso en La Paz, Bolivia, p. 52, 2006.

BRAZIL. Bolsa Família. 2003. Available at: http://www.nds.gov.br/bolsafamilia

. MDS - Ministério do Desenvolvimento Social e Combate à Fome. 2004.

[Accessed 20 October 2018]. Available at: http://mds.gov.br/

BUSSANI, M. II diritto dell'occidente. Geopolitica delle regole globali. Einaudi, Torino, 2010

CAPRA, F.; MATTEI, U. Ecologia del diritto. Scienza, politica, beni comuni. trad. di I. Mattei, Sansepolcro. 2017.

CATACORA-VARGAS, G.; et. al., Brief historical review of agroecology in Bolivia, Agroecology and Sustainable Food Systems, 41, 2017, p. 429-447, DOI: 10.1080/21683565.2017.1290732.

CLAPHAM, A. Human Rights in the Private Sphere. Oxford, Clarendon Press, 1983

COOMANS, F. The Ogoni Case Before The African Commission on Human and Peoples' Rights. In: International and Comparative Law Quarterly, 52, 2002.

DAN-MUSA, I. Implications of Gas Flaring to the Nigerian Environment and Economy. $2013 . \quad$ Available at: https://www.academia.edu/11818230/IMPLICATIONS_OF_GAS_FLARING_TO_THE _NIGERIAN_ENVIRONMENT_AND_ECONOMY, accessed at 25-03-2019.

DE GRAUWE, P. I limiti del mercato. Da che parte oscilla il pendolo dell'economia?. Bologna, II Mulino, 2018.

DREZE, J.; SEN, A. Hunger and public action. Clarendon, Oxford, 1991.

DWORKIN, R. Introduction to Taking Rights Seriously. Massachusetts: Harvard University Press, 1977.

ELVER, $\mathrm{H}$. Access to justice and the right to food: the way forward, Human Rights Council, Twenty-eighth session Agenda item 3, 2014, A/HRC/28/65

FAO. "Right to Food: Making it Happen: Progress and Lessons Learned through Implementation", in Right to Food Publications, 2011.

FEDERAL REPUBLIC OF NIGERIA. Constitution of the Federal Republic of Nigeria. 1999. 
FERRAJOLI, L. Diritti fondamentali. Un dibattito teorico, I ed., a cura di E. Vitale, Roma-Bari, Laterza, 2001.

FORNO, F.; GRAZIANO, P. R. II consumo critico, Bologna, 2016.

FRIEDMANN, H.; MCMICHAEL, P. "Agriculture and the state system. The rise and decline of national agricultures, 1870 to the present". In: Sociologia Ruralis, XXIX:2, 1989.

GERSEN, J., et al., Food Law and Policy. New York, Wolter Kluwer, 2018.

GOLAY, C. The right to food and the access to justice. Examples at the national, regional and international levels, Roma, FAO, 2009

GUBERT, M. B.; et. al. A municipal-level analysis of secular trends in severe food insecurity in Brazil between 2004 and 2013. Global Food Security, 14, 2017.

GULATI, A.; et al. "National Food Security Bill, Challenges and Options, Discussion Paper No. 2" (December 2012). Commission on Agricultural Costs and Prices, Ministry of Agriculture, Government of India; National Food Security Bill, Registered No. DL(N)04/0007/2003-13, as published by the Ministry of Law and Justice, September 10, 2013, http://egazette.nic.in/WriteReadData/2013/E_29_2013_429pdf accessed at 28-10-2018.

IANNARELLI, A. Cibo e diritti: Per un'agricoltura sostenibile, Torino, 2015.

IMBRENDA, M. Le relazioni contrattuali nel mercato agroalimentare, Napoli, Esi, 2016.

INDIA. National Food Security Act (NFSA). 2013. Available at: https://dfpd.gov.in/nfsa.htm

IRTI, N. Norma e luoghi. Problemi di geo-diritto, Roma-Bari, Laterza, 2001.

; SEVERINO, E. Dialogo su diritto e tecnica, Laterza, Roma-Bari, 2001.

ISMAIL, O.; UMUKORO, G. Global Impact of Gas Flaring. In: Energy and Power Engineering, vol. 4, n. 4, 2011

JÄGERS, N. Corporate Human Rights Obligations: in Search of Accountability, Antwerp-Oxford-New York: Intersentia, Netherlands School of Human Rights Research Series No. 17, 2002, ch. III.

KLEIN, N. The Shock Doctrine: The Rise of Disaster Capitalism, Metropolitan Books, New York, 20017. 
KNUTH, L.; VIDAR, M. "Constitutional and Legal Protection of the Right to Food Around the World". In: FAO Right to Food Studies, 2011. Available at: www.fao.org/docrep/016/ap554e/ap554e.pdf accessed at 10 October 2019.

LAMBEK, N.; CLAEYS, P. "Institutionalizing A Fully Realized Right To Food: Progress, Limitations, And Lessons Learned From Emerging Alternative Policy Models". In: Vermont Law Review, 40, 2016.

LEÃO, M.; MALUF, R. Effective Public Policies and Active Citizenship: Brazil's experience of building a Food and Nutrition Security System, ABRANDH, Brasilia, 2012.

MENGONI, L. Diritto e valori. Bologna, II Mulino, 1985.

MINKLER, A.; PRAKASH, N. The Role of Constitutions on Poverty: A CrossNational Investigation, IZA Discussion Paper No. 8877. Available at SSRN: https://ssrn.com/abstract=2575057. 2015.

MONATERI, P.G. Geopolitica del diritto. Genesi, governo e dissoluzione dei corpi politici, Roma-Bari 2013.

NICOLINI, M. The principle of Separation and Correspondence, the Comparative Method and the Problem of Semantic Change. In: Comparing Fiscal Federalism, VALDESALICI, A.; PALERMO, F. ed., Brill Nijhoff, Leiden-Bristol, 2018.

PEGORARO, L.; RINELLA, A. Sistemi costituzionali comparati, Giappichelli, Torino, 2017

PENNASILICO, M. "Contratto, ambiente e giustizia dello scambio nell'officina dell'interprete". In: Politica del diritto, 1, 2018.

PERLINGIERI, P. II diritto civile nella legalità costituzionale secondo il sistema italo-comunitario delle fonti, 3ed., 2006. Esi, Napoli.

PISTOR, K. The Code of Capital: How the Law Creates Wealth and Inequality, Princeton University Press, 2019.

PRETEROSSI, G. "I diritti alla prova del 'politico". In: Ragion Pratica, 28, 2008.

RICHARDS, C.; LAWRENCE, G.; BURCH, D. Supermarkets and agro-industrial foods: The strategic manufacturing of consumer trust. Food, Culture \& Society, v. 14, n. 1, p. 29-47, 2011.

RINELLA, A. “Food Sovereignty”. In: Riv. quad. dir. amb., 1, 2015.

RODOTÀ, S. II diritto al cibo. I Corsivi (e-book), 2014. 
ROSSI, G. Diritto dell'ambiente e diritto dell'alimentazione. In: Riv. quadr. dir. amb., 2015.

SHIVA, V. Who really feeds the world?: The failures of agribusiness and the promise of agroecology. North Atlantic Books, 2016.

STEYN, P. Oil Ethnic Minority Groups and Environmental Struggles Against Multinational Oil Companies and the Federal Government in the Nigerian Niger Delta since the 1990s. In: A History of Environmentalism: Local Struggles, Global Histories, ed. Armiero M.; Sedrez, L. London, New Dehli, New York, Sidney, Bloomsbury, 2014.

TARELLO, G. Storia della cultura giuridica moderna. Vol. I, Assolutismo e codificazione del dirittto, Bologna, II Mulino, 1976.

THE Rice Bomber. Directed by: Cho Li. Germany, 2014. 1h 58m.

WALLACE, T. The Challenge of Food: Nigeria's Approach to Agriculture 1975-80. In: Canadian Journal of African Studies/Revue canadienne des études africaines, $15,2,1981$

WESTRA, L. "The many facets of Food". In: On Hunger: Science Ethics and Law, Irvine Boca Raton, Universal Publishers, Inc., USA, 2017.

ZAGREBELSKY, G. "Diritto per valori, principi o regole". In: Quaderni Fiorentini, 31, 2, 2002.

ZENGERLING, C. Greening International Jurisprudence: Environmental NGOs before International Courts, Tribunals, and Compliance Committees, Martinus Nijhoff Publishers, 2013

ZIEGLER, J. Promotion and Protection of All Human Rights, Civil, Political, Economic, Social and Cultural Rights, Including the Right to Development, at para. 17, U.N. Doc. A/HRC/7/5. Jan. 10, 2008.

"The Right to Food of the Most Vulnerable People". In: The Fight for the Right to Food. Lessons Learned, Palgrave Macmillan UK, 2011. 